\title{
Therapeutic potential of camel milk
}

\author{
Uma Shukla Dubey', Manohar Lal' ${ }^{1}$, Anyaa Mittal', Suman Kapur ${ }^{2}$ \\ ${ }^{1}$ Birla Institute of Technology and Science, Pilani, Pilani Campus, Rajasthan, India; ${ }^{2}$ Birla Institute of Technology and Science, Pilani, Hyderabad \\ Campus, Andhra Pradesh, India
}

\section{A B S T R A C T}

\begin{abstract}
Camel milk is recognized for its therapeutic potential against many diseases. It is reported to have microbicidal and immuno stimulatory properties as it contains immunoactive proteins like lysozyme, lactoperoxidase and lactoferrin. Camelid antibodies have a unique structure. They possess the heavy chains but are devoid of the usual light chains. This special feature enhances their penetration. Camelid proteins have a very high degree of thermal stability and are resistant to acid hydrolysis. Camel milk components act like a ligand to the aryl hydrocarbon receptor. They significantly inhibit the induction of some cancer-activating genes and also induce tumor suppressor genes. Modulation of aryl hydrocarbon receptors is now recognized to have a vital role in cancer therapy. The present review deals with clinical significance of camel milk with special reference to cancer. It also encompasses its unique composition, relevance to other diseases and special properties as compared to human milk.
\end{abstract}

Keywords: Antibodies; Camel; Cancer; Disease; Milk

\section{INTRODUCTION}

Over millenniums nature has evolved to ensure survival of diverse species against adverse environmental and pathological conditions. In case of mammals, maternal milk has paramount preventive and therapeutic benefit against vast variety of diseases, including cancer. Numerous studies in humans testify the immunological potential of human milk (Davanzo et al., 2012; Davis, 1998; Harikrishnan, 2006; Mathur et al., 1993; Newman, 1995; Parodi, 2007; Shamsia, 2009; Singh et al., 2012). The global epidemic of cancer is rising with this disease killing more people across the world than tuberculosis, AIDS, and malaria combined. According to GLOBOCAN, an estimated 14.1 million new cancer cases and 8.2 million cancer-related deaths occurred in 2012. This amounts to nearly $13 \%$ of all deaths. By 2030, the global cancer burden is expected to mount by about $75 \%$, increasing to 21.4 million new cases and culminating in 13.2 million deaths (Bray et al., 2013). Cure of cancer still remains a worldwide challenge.

Camel milk not only serves as a nutritional supplement well adapted to human needs but also has microbicidal and immuno-stimulatory properties (El-Agamy et al., 1992; El-Fakharny et al., 2008; Hamad et al., 2011; Shabo et al., 2005; Yagil, 2013). It has been traditionally believed in the Middle Eastern countries that camel milk has both preventive and therapeutic potential against cancer. Recently there have been many upcoming scientific evidences to lend support to this belief (Korashy et al., 2012a; Korashy et al., 2012b; Magjeed, 2005). Camel milk is generally consumed without boiling, thereby retaining its various biological and immunological properties that are normally lost in milk preservation processes (Agrawal et al., 2007). Camel is a mammal well adapted to deal with stressful conditions like high temperature and water deficiency (Faye, 2014). Its proteins are highly thermo-stable and resistant to acid hydrolysis (Maliheh et al., 2011). The ability of camel to withstand elevated temperatures may be useful in killing pathogenic thermo sensitive infectious agents. This may be the speculated cause behind the so called pathogen free state of its milk. Therefore, camel milk rarely ever causes any disease even though it is normally consumed raw.

Camel milk is supposed to have medicinal properties (El-Agamy et al., 1992). It is expected to have a therapeutic potential against many diseases including cancer. It has long been utilized for its benefit in broad range of diseases like Insulin Dependent Diabetes Mellitus (IDDM) (Agrawal et al., 2002; Agrawal et al., 2003; Agrawal et al., 2005), 
infant diarrhea (Yagil, 2013), hepatitis (El-Fakharany et al., 2008), allergy, lactose intolerance (El-Agamy et al., 2009; Konuspayeva et al., 2009; Cardoso et al. 2010) and alcohol induced liver damage (Ahmed et al., 2011). Its benefits can be attributed to the presence of many immunologically important molecules such as lysozymes, lactoferrin, lactoperoxidase, etc. (El-Agamy et al., 1996). The level of lactoferrin is comparable to cow's milk although its bioactivity is slightly higher (Konuspayeva et al., 2006; Conesa et al., 2008). It contains extraordinarily high levels of insulin like molecule (Agrawal et al.,2002; 2003; 2005). Besides this, its antibodies have a very specialized structure and function which may lead to its therapeutic benefit by modulating the immunoregulation. Camels unlike all other species (except shark) produce very special antibodies devoid of any light chains yet fully capable of antigen binding (De Genst et al., 2006; Desmyter et al., 2001; Hamers-Casterman et al., 1993; Harmsen et al., 2000; Harmsenand DeHaard, 2007; Muyldermans et al., 1994; Nguyen et al., 2000; Spinelli et al., 1996; Van der Linden et al., 1999; Vu et al., 1997; Yoo et al., 1967). Heavy chain antibodies can be expressed in microorganisms and have a high stability and solubility. Furthermore, camel milk IgGs are well suited for construction of larger molecules. It can also be used for selection systems such as phage, yeast, or ribosome display (Harmsen and DeHaard, 2007). Therefore the special features of these antibodies and the presence of other biologically important molecules and/or their derivatives confer camel milk with unique medicinal properties.

It is a commonly expected notion that proteins/polypeptides are enzymatically broken down completely to amino acids before their assimilation. It has been observed that there exist cellular mechanisms by which proteins/large polypeptides maybe carried across the cell intact. These molecules cross the basolateral border by co-transporters and facilitated transporters. Some large peptides or proteins can be carried across the cell by transcytosis. This is particularly true in infants where the intestinal tract is not completely developed and the $\mathrm{pH}$ of stomach is not as low as adults. It is the mechanism whereby the immunoglobulins in maternal milk along with all its immunological properties is transferred to the child. The enterocytes that do this are probably situated in the Crypts of Lieberkuhn. This mechanism also operates in adults but to a lesser extent. It has been observed that, indeed in infants the openings to the pits are much wider than in older children and adults (Gullberg, 2005; Ziv and Bendayan, 2000).

To prevent degradation of protein drugs from action of digestive juices in the stomach and to further enhance their absorption, various agents and techniques have been developed. Certain enzyme inhibitors like pancreatic inhibitor, soybean trypsin inhibitor and aprotinin have been used to minimize the degradation of protein drugs by various proteolytic enzymes (Laskowski et al., 1958; Yamamoto et al., 1994). Absorption of protein drugs through intestinal walls could be improved using absorption enhancers which include surfactants, detergents, bile salts and Ca2+ chelating agents (Aungst, 2000; LeCluyse and Sutton, 1997). Researchers have also designed mucoadhesive polymeric systems which are capable of extending the residence time for protein drugs at their site of absorption (Hejazi and Amiji, 2003; Peppas, 2004). On the similar lines, various particulate carriers have been used to deliver protein drugs via the oral route. These carriers include nanoparticles, microspheres and liposomes. They play a vital role in preventing the degradation of protein drugs in the harsh environment of the GI tract (Okada et al., 1998; Singh et al., 2008; Behrens et al., 2002).

\section{Anti-cancer properties of milk}

Animal models for colon and mammary tumorigenesis have shown that whey proteins are better than other dietary proteins in suppressing tumor development (Parodi, 2007).

\section{Survival value of maternal milk}

Milk has a wide range of immunological molecules that enhance the survival value of infants feeding on mother's milk directly. Many of these molecules are present across mammalian species. Human milk too has numerous compounds with immune modulatory, antimicrobial and anti-neoplastic properties and/or the combination of the above. It also contains various bioactive components having an anti-cancer action. Some vital biologically active molecules present in milk are listed in Table 1.

Some molecules with anti-cancer activity present in human milk are Conjugated linoleic acids (CLAs), lactoferrin, TRAIL (TNF-related apoptosis inducing ligand) and HAMLET (Human alpha-lactalbumin made lethal to tumors). Structurally and functionally similar molecules with anti-cancer properties have been discovered in milk across diverse mammalian species (Zhang et al., 2009). For example, HAMLET, a conjugate of $\alpha$-lactalbumin and oleic acid, is an antitumor biomolecule known to act not only against a wide range of cell lines, but also against some human tumors. It has shown significant positive response in treating glioblastomas skin papillomas, and bladder cancers. Interestingly, a variety of HAMLET-like substances from milk of other mammalian species have been discovered (Zhangetal., 2009). These molecular species with anticancer activity have been referred to as XAMLET, just for the sake of generalization.

Recently, the toxicity of bovine $\alpha$-lactalbumin made lethal to tumor cells (BAMLET) has also been studied against cell lines. The toxicity of raw bovine milk is highly dependent 
Table 1: Bioactive components in human milk

\begin{tabular}{|c|c|c|c|c|}
\hline Type of molecule & $\begin{array}{l}\text { Biomolecule present } \\
\text { in milk }\end{array}$ & $\begin{array}{l}\text { Biochemical } \\
\text { nature }\end{array}$ & Significant property & Reference \\
\hline \multirow[t]{4}{*}{ Immunomodulatory } & Fibronectin & Glycoprotein & $\begin{array}{l}\text { Increases antimicrobial activity of macrophage } \\
\text { Carcinoma development }\end{array}$ & $\begin{array}{l}\text { Goldsby et al., 2003; } \\
\text { Han et al., } 2006\end{array}$ \\
\hline & $\begin{array}{l}\text { Hormones and growth } \\
\text { Factors }\end{array}$ & $\begin{array}{l}\text { Peptides and } \\
\text { proteins }\end{array}$ & Development of infants GIT against microbes & Newman, 1995 \\
\hline & Interferons & Proteins & $\begin{array}{l}\text { Enhances antimicrobial activity of immune } \\
\text { competent cells and signals adjacent cell } \\
\text { on being virally infected to take preventive } \\
\text { measure }\end{array}$ & Watanabe, 2004 \\
\hline & Lactoferrin & $\begin{array}{l}\text { Globular } \\
\text { glycoprotein }\end{array}$ & $\begin{array}{l}\text { Makes Iron unavailable for bacteria thereby } \\
\text { inhibiting its growth } \\
\text { Enhances lactose tolerance }\end{array}$ & $\begin{array}{l}\text { El-Fakharany, et al., 2008; } \\
\text { Cardoso et. al., 2010; } \\
\text { Conesa et al., } 2008 .\end{array}$ \\
\hline \multirow[t]{7}{*}{ Antimicrobial } & $\begin{array}{l}\text { Secretory } \\
\text { Immunoglobulins }\end{array}$ & Glycoproteins & $\begin{array}{l}\text { Prevent microbial infiltration in tissue by } \\
\text { blocking entry }\end{array}$ & $\begin{array}{l}\text { Harmsen et al.,2007; } \\
\text { Cortez et al.,2002 }\end{array}$ \\
\hline & $\mathrm{B}_{12}$ binding protein & Protein & $\begin{array}{l}\text { Retards bacterial growth by reducing the } \\
\text { amount of available vitamin } B_{12}\end{array}$ & Newman, 1995 \\
\hline & Fatty acids & Lipid & Disruption of some viral membrane & Newman, 1995 \\
\hline & Bifidus factor & $\begin{array}{l}\text { methyl-N-acetyl } \\
\text { D-glucosamine }\end{array}$ & $\begin{array}{l}\text { Promotes growth of harmless } L \text {. Bifidusto out } \\
\text { compete pathogenic strains }\end{array}$ & Newman, 1995 \\
\hline & Lysozyme & Protein & Kills bacteria by disrupting its wall & El-Agamy et al., 1992 \\
\hline & Mucins & $\begin{array}{l}\text { Glycosylated } \\
\text { proteins }\end{array}$ & $\begin{array}{l}\text { Prevent bacterial \& viral attachment to } \\
\text { mucosal surfaces }\end{array}$ & Newman, 1995 \\
\hline & Oligosaccharides & Carbohydrates & $\begin{array}{l}\text { Prevent microbes from binding to mucosal } \\
\text { surface by attaching to the microbes }\end{array}$ & Newman, 1995 \\
\hline \multirow[t]{5}{*}{ Anticancer } & Lactoferrin & $\begin{array}{l}\text { Globular } \\
\text { glycoproteins }\end{array}$ & $\begin{array}{l}\text { Induction of apoptosis, inhibition of } \\
\text { angiogenesis and modulation of carcinogen } \\
\text { metabolizing enzymes }\end{array}$ & El-Agamy et al., 1996 \\
\hline & Casein and its peptides & Phosphoproteins & Antimutagenic properties & Parodi et al.,2007 \\
\hline & $\begin{array}{l}\text { TRAIL (TNF-related } \\
\text { apoptosis inducing ligand) }\end{array}$ & $\begin{array}{l}\text { Cytokine } \\
\text { (proteins) }\end{array}$ & $\begin{array}{l}\text { A member of TNF family, kills cancer cells } \\
\text { in vitro and in vivo }\end{array}$ & Horinaka et al., 2010 \\
\hline & XAMLET & Lipoprotein & $\begin{array}{l}\text { Induces cell death in certain cancers and cell } \\
\text { lines without effecting normal tissue }\end{array}$ & Zhang et al., 2009 \\
\hline & $\begin{array}{l}\text { CLA (conjugated } \\
\text { linoleic acids) }\end{array}$ & Fatty Acid & Antimutagenic activity & Amarù et al., 2009 \\
\hline
\end{tabular}

on oleic acid and induces killing in cancer cell lines but up to now only human milk has been most predominantly studied. There is a conservation of molecules in evolutionarily closely related species thus it is likely that homologous molecules may also be present in other mammalian species. We postulate the presence of similar molecule in camel milk (CAMLET), because camel milk too, is known to possess relatively high concentration of oleic acid and alpha lactalbumin (Konuspayeva et al., 2008).

Supplementing cow's milk with selenium increases the content of selenoproteins in milk. These selenoproteins on isolation were able to inhibit colon tumor genesis in rats (Parodi, 2007).In the traditional Indian system of medicine, namely Ayurveda, raw cow's milk and its derivatives have also been used as a component of various medicines against wide range of ailments (Harikrishnan, 2006).

\section{Epidemiological evidences of anti-cancer properties of Human milk}

Epidemiological evidences strongly suggest benefits of mother's milk against cancer in humans. A qualitative review assessing the association between infant feeding and childhood cancer was undertaken by Davis et al., in 1998. The results of suggested that children who were never breast-fed or fed for short-term ( $<6$ months) were at a higher risk of developing Hodgkin's lymphoma. In another study, the total duration of breastfeeding and of exclusive breastfeeding was compared in 99 childhood cancer cases and 90 controls. The outcome suggested that breast feeding had a protective effect against childhood cancer. The study also indicated that exclusive breast feeding provided more beneficial immunological effects than breast feeding supplemented by artificial feeding (Mathur et al., 1993). The high rate of breast feeding in India may explain the low incidence of childhood cancer in India as compared to many countries such as Israel (6/100,000 vs. 18/100,000 respectively).

There exists no substitute for mother's milk in any mammalian species other than humans. In animals, infants deprived of mother milk are likely to simply die away due malnutrition and disease. The research conducted in human shows presence of vital immunological factors 
in milk (Goldsby et al., 2003). Similar benefits are likely in other mammalian species too although not many studies have been done. Benefits of maternal milk may be presumed because there is an evolutionary preservation of vital molecules, required for survival, across diverse species. Molecules present in maternal milk may help to optimize the function of the immune system and regulate cell proliferation to avoid tumor development in the rapidly growing neonatal cells.

\section{Anticancer molecules present in human milk}

The anti-cancer properties of human milk are far better studied than any other species. Before emphasizing upon the anticancer properties of camel milk it might be relevant to appreciate some evolutionarily conserved relevant molecules from human milk with an anti-cancer property. As we shall see later, many of these are also present in camel milk.

\section{HAMLET (Human $\alpha$ - lactalbumin made lethal to tumors)}

HAMLET is a very promising anticancer agent derived from human milk. It induces massive cell death in various types of cancers without causing any damage to normal tissues. In vitro it was able to induce programmed cell death in many human and murine cell lines such as Jurkat, L1210 (a leukemia cell line), A549 (a lung carcinoma line), and A-498 (a kidney carcinoma cell line). It also effectively destroys a great variety of tumor cells ranging from carcinomas of lung, throat, kidney, colon, bladder, prostate, ovaries; melanomas, to glioblastomas of the brain and leukemia (Svensson et al., 2000; Spolaore et al., 2010).

Mossberg et al., (2007) examined the effect of HAMLET on plasma membrane vesicles (PMVs) obtained from tumor cells. The treatment of bladder tumors by intravesicle HAMLET delivery resulted in a significant reduction in 8 out of 9 treated patients. HAMLET has shown striking effects in a rat model xenografted with human glioblastomas (Fischer, 2004).

HAMLET treated cells underwent shrinkage, nuclear condensation, caspase activation and DNA fragmentation, the characteristic features of programmed cell death (Hakansson et al.,1995). HAMLET-induced cell death is p53-independent and it also triggers an autophagic response (Aits et al., 2009). HAMLET not only translocates into tumor cells, activates cell death pathways but also induces adherent cell detachment in vitro (Trulsson et al., 2011). It also triggers tumor cell detachment in vivo in bladder cancer patients (Mossberg et al., 2007).

The interaction of tumor cell plasma membrane with HAMLET results in change in the fluidity of lipid bilayer leading to membrane elongation (Mossberg et al., 2010).
Membranes of tumor cells have altered lipid composition and fluidity. This may alter membrane-bound receptors and endocytic pathways and thereby affecting the activation of cell death in a manner that discriminates tumor cells from normal cells. After passing through the first barrier of plasma membrane, HAMLET enters cytoplasm and translocates into the nucleus (Duringer et al., 2003). HAMLET, being a partially unfolded protein, triggers endoplasmic reticulum stress signal in the cytoplasm, and is directed to $20 \mathrm{~S}$ proteosome for degradation. Here it triggers a change in structure of proteosome and resists its own degradation by proteolytic enzymes (Gustafsson et al., 2009). In the nucleus histone proteins, mainly H3 and $\mathrm{H} 4$ act as nuclear receptors for HAMLET. In their study in 2007, Brest et al., have shown that histone deacytylase inhibitors enhance the tumoricidal effects of HAMLET. They acted by enhancing the hyperacetylation response which disrupts chromatin structure.

\section{TNF - Related Apoptosis Inducing Ligand (TRAIL)}

TRAIL is a member of the tumor necrosis factor (TNF) super family of cytokines. It may be present either in a trans-membrane form or occur in the cytoplasm as a soluble protein. Extremely high levels of TRAIL have been detected in human colostrum and milk (Davanzo et al., 2012). TRAIL is a pleiotropic cytokine with important functions in regulating immune response and inflammation. It plays a key role in controlling cell death and cell proliferation in various organs and tissues. The best characterized activity of TRAIL is its ability to kill cancer cells both in vitro and in vivo. It is currently being used as a recombinant protein in many clinical trials against a wide variety of human cancers. Moreover, it has recently been shown that certain Lactobacillus strains induce the production of TRAIL. This further facilitates natural killer activity against cancer cells (Horinakaet al., 2010). Endogenous soluble TRAIL itself represents a strong candidate to explain the overall biological effect of breastfeeding against cancer.

\section{Immunological and anti-cancer properties of casein and whey components of milk}

Many milk components act not only as nutrients but also have very important immunological and anticancer properties. Casein breakdown products have the ability to prevent mutations. The high content of cystine/cysteine and gamma-glutamylcyst(e)ine dipeptides have been implicated for this activity. Dipeptides are efficient substrates for the synthesis of glutathione. Glutathione is a well-known ubiquitous cellular antioxidant that either directly or through its associated enzymes destroys reactive oxygen species (ROS). It also detoxifies carcinogens, maintains proteins in a reduced state and ensures immunocompetence. Increased glutathione levels 
in serum and tissues accompany tumor prevention by dietary whey proteins. Enhanced glutathione level has been found to be associated with an enhanced spleenocyte proliferation and phagocytosis. It is also involved in immune regulation by $\mathrm{T}$ Helper cells, cytotoxicity mediated by natural killer cells and CTLs. The minor whey component, lactoferrin, inhibits intestinal tumors. It acts by inducing apoptosis, inhibiting angiogenesis and modulating carcinogen metabolizing enzymes. It also acts as an iron scavenger (Parodi, 2007).

\section{Medicinal value of camel milk}

Camel milk is emerging as a potent therapeutic alternative which can help in reducing insulin doses in diabetic patients. It's well established role in management of Diabetes has rendered it the title of "white gold of desert". Epidemiological surveys strongly indicate low prevalence of diabetes in communities consuming camel milk. (Agrawal et al., 2013). Global market potential for camel milk needs to be further exploited.

Camel milk has been successfully used in the treatment of various diseases such as diabetes (Agrawal et al., 2002; Agrawal et al., 2005), hepatitis (El-Fakharany, 2008), allergy (El Agamy et al., 2009) and to counter alcoholism (Ahmed et al., 2011) as explained in Table 2. Similar to human milk as described earlier, camel milk also contains protective proteins like lysozyme, lactoperoxidase, lactoferrin, polypeptide recognition protein and $\mathrm{N}$-acetyl-beta-D-glucosamidase (Shamsia, 2009; El-Agamy et al., 1996).

Camel milk has an amazing immunological profile. It contains very special types of immunoglobulins called the
VHH (variable heavy heavy) antibodies or Nanobodies. Camel antibodies are much smaller in size as compared to the normal antibodies as they lack the typical light chains present in normal antibodies. This increases their tissue penetration while retaining the specificity (Harmsenand De Haard, 2007; Cortez et al., 2002). Camel IgGs (which also exist in the milk, besides being present in blood) are able to penetrate within tissues unlike human IgGs. Therefore, they are able to enter into organs like liver and kidney. Furthermore, they can enter inside a cell where they may perform various functions under pathological conditions (Al-Fartosi et al., 2011; Mohamed, 2010; Jadambaa et al., 2000; Hamad et al., 2011; Sharmanov and Kadyrova, 1978). As mentioned earlier, camel milk lactoferrin also has anti-viral and anti-bacterial properties (El Agamy, 1996; Konuspayeva et al., 2006).

\section{Special composition of camel milk}

Functional foods and their dietary constituents have a well-established beneficial role in health promotion and have emerged as an adjunct for cancers chemoprevention (Kontou et al., 2011). Camel milk is given to the sick, elderly and very young because of the belief that it is not only healthier, but works especially well in bone formation. A high content of unsaturated fatty acids (such as oleic acid) further improves its overall dietary quality (Konuspayeva et al., 2009; Jadambaa, 2000; Nikkhah, 2011; Shabo et al., 2005; Shamsia, 2009; El-Agamy et al., 2009).

Camel milk is mostly consumed fresh and raw by some native communities in India. In this way its medicinal properties are not destroyed by preservation techniques like boiling, pasteurization, etc., Also it does not form coagulum in acidic environment (Wangoh et al., 1998). This lack of

Table 2: Application of camel milk in various diseases

\begin{tabular}{|c|c|c|c|}
\hline S. no. & Treatment against disease conditions & Molecule implicated & Reference \\
\hline 1. & Diabetes & Insulin like molecule & $\begin{array}{l}\text { Agrawal, et al., 2013; } \\
\text { Agrawal, et al., 2002; } \\
\text { Beg et al., 1986; } \\
\text { Singh, } 2001\end{array}$ \\
\hline 2. & Hepatitis C Virus & Amylase \& lactoferrin & El-Fakharany, 2008 \\
\hline 3. & Allergy & $\begin{array}{l}\text { Low levels of } \beta \text {-Casein \& lack of } \\
\beta \text {-lactalbumin }\end{array}$ & $\begin{array}{l}\text { El Agamy et al., } 2009 \\
\text { Shabo et al., } 2005\end{array}$ \\
\hline 4. & Liver and kidney function & $\begin{array}{l}\text { Alanine amino transferase and } \\
\text { aspartate aminotransferase }\end{array}$ & $\begin{array}{l}\text { Hamad et al., 2011; } \\
\text { Jadambaa et al., 2000; } \\
\text { Sharmanov et al., } 1978\end{array}$ \\
\hline 5. & Slimming properties & $\begin{array}{l}\text { Low protein content and } \\
\text { reasonable cholesterol content }\end{array}$ & $\begin{array}{l}\text { Yasin and Wahid, } 1957 \\
\text { Faye et al., } 2015\end{array}$ \\
\hline 6. & Bacterial infection & Lysozyme, lactoperoxidase & El Agamy et al., 1992 \\
\hline 7. & Nutritional supplements & Unsaturated fatty acids & Konuspayeva et al., 2009 \\
\hline 8. & Immuno enhancer & Peptidoglycan recognition protein & El Agamy et al., 1992 \\
\hline 9. & $\begin{array}{l}\text { Lactase deficiency and easy } \\
\text { assimilation }\end{array}$ & L-lactate & $\begin{array}{l}\text { Cardoso et al., 2010; } \\
\text { Baubekova et al., } 2015\end{array}$ \\
\hline 10. & Bone formation & High level of calcium & Riad et al., 1994 \\
\hline 11. & Diarrhea & High level of sodium and potassium & $\begin{array}{l}\text { Yagil, 2013; } \\
\text { El Agamy et al., } 2009\end{array}$ \\
\hline
\end{tabular}


coagulum formation allows the camel milk to pass rapidly through stomach with proteins available for absorption in intestine. The $\mathrm{pH}$ of camel milk is between 6.5-6.7. Camel milk is different from other ruminant milk because it has reasonable content of cholesterol, high minerals (sodium, potassium, iron, copper, zinc and magnesium), high vitamin C, B2, A and E, low protein and high concentrations of an insulin-like protein (Konuspayeva et al., 2009; Shamsia, 2009; Faye et al., 2015).

One liter of camel milk has ample amount of minerals to meet $100 \%$ of the daily human requirements for calcium and phosphorus, $57.6 \%$ for potassium, $40 \%$ for iron, copper, zinc and magnesium, and $24 \%$ for sodium. It helps treat liver problems, lowers bilirubin output, lightens vitamin inadequacy and nutrient deficiency, besides boosting immunity. Camel milk contains substantially less vitamins $\mathrm{A}$ and $\mathrm{B} 2$, similar vitamin $\mathrm{E}$ content and about 3-10 times greater vitamin C as compared to cow milk (Nikkhah, 2011; Konuspayeva et al., 2011).

In the Middle Eastern countries fresh butter derived from camel milk is often used as a base for many medicines. Not only is it totally devoid of any allergic properties but it also heals food allergies and gut problems. It can be conveniently consumed by lactase deficient people and even by those who have a weak immune system. The hypo-allergic effect of camel milk is associated with a low level of beta-casein and lack of beta-lactoglobulin. This milk also apparently has slimming properties attributed to camel milk owing to its cholesterol level, which however remains a matter of debate (El-Agamy et al., 2009; Faye et. al., 2015).

\section{Immunologically important molecules in camel milk (Table 3)}

Medicinal properties present in camel milk have been attributed to a wide array of immunologically significant protective proteins present in it. The level of peptidoglycan recognition protein (PRP) is very high in camel milk. PRP not only stimulates the host's immune response but also has an antimicrobial activity (El-Agamy et al., 1992). It acts by preventing microbial overgrowth and inhibiting pathogenic invasion. Recent studies have shown that the amount of Lactoferrin is almost similar to that in cow milk however its bioactivity is higher (Konuspayeva et al., 2006; Conesa et al., 2008). The camel milk has the same quantity of sugar (lactose) but the only difference is the better lactose tolerance for consumers (Cardoso et al., 2010). Lactoperoxidase present in camel milk has bactericidal activity on gram-negative bacteria. Its antitumor activity has also been suggested. Lysozyme is a part of the soluble components of the innate immune system and targets gram-positive bacteria. $\mathrm{N}$-acetyl-beta-D-glucosamidase is found in similar quantities as in human milk where it has antibacterial activity. Lactoferrin, lactoperoxidase, lysozyme, immunoglobulin $G$ and secretory immunoglobulin A were extracted from camel milk (El-Agamy, 1992). The activity of these protective proteins was assayed against Lactococcus lactis, Escherichia coli, Staphylococcus aureus, Salmonella typhimurium $\&$ rotavirus and compared with egg white lysozyme, bovine lysozyme and bovine lactoferrin. The spectrum of antibacterial activity of camel milk lysozyme was similar to that of egg white lysozyme, but differed from bovine milk lysozyme. The camel milk lactoperoxidase was bacteriostatic against the gram-positive strains and was bactericidal against gram-negative cultures. The immunoglobulins had little effect against the bacteria but high titers of antibodies against rotavirus were found in camel milk. The lactoperoxidase system was ineffective against rotavirus (El-Agamy et al., 1996).

As compared to human milk, camel milk has a higher ratio of immunoglobulins but a lower ratio of both lysozyme and lactoferrin. A comparative lipid profile indicates that the short chain fatty acids (C4-C12) although were present in small amounts but they were higher than in human milk fat. On the contrary the concentration of higher chain fatty acids such as C14:0, C16:1 and C18:0 were relatively high in camel's milk fat as compared to human milk fat. Appreciable amounts of essential fatty acids were also present in camel milk (Shamsia, 2009; Konuspayeva et al., 2009).

Ahmed et al., in 2011 studied the role of camel milk in the reactivation of liver damage caused by Sudanese liquor, popularly known as Aragi. Their study showed a statistically significant increase in the liver enzyme markers in the group given liquor as compared to the controls. Camel milk was observed to reduce the level of vital liver enzymes. It was thus suggested that camel milk can be used as a remedy for treatment of alcoholism and other liver diseases.

A study was conducted to see if the consumption of camel milk was beneficial for diabetes. A significant improvement in glycosylated hemoglobin (HbA1c) and fasting blood sugar levels was observed. Also a significant reduction in insulin requirement in patients receiving camel milk was noted. Although there was a 30\% reduction in doses of insulin in $92 \%$ of patients but there were no statistically significant change in lipid profile, plasma insulin and c peptide (Agrawal et al., 2003; Agrawal et al., 2007).It has been reported that one of its milk protein has many characteristics similar to insulin (Beg et al., 1986).

Camel proteins are able to maintain a high degree of thermal stability and remain functional even at elevated temperatures. Their extraordinary stability is attributed mainly to their 
Table 3: Molecules with immune function in camel milk

\begin{tabular}{|c|c|c|c|}
\hline S. no. & Name of molecule & Function & Reference \\
\hline 1. & $\begin{array}{l}\text { Heavy chain antibodies }(\mathrm{HCAb}) \text { or } \\
\text { variable heavy antibodies }(\mathrm{VHH}) \text { or } \\
\text { nanobodies }\end{array}$ & $\begin{array}{l}\text { Able to interact with less immune dominant } \\
\text { parts of antigens } \\
\text { More tissue penetration but similar specificity } \\
\text { Equivalent specificity } \\
\text { Rapid renal clearance in human }\end{array}$ & $\begin{array}{l}\text { Hamers-Castermanet al. (1993); } \\
\text { Muydermans, } 2013\end{array}$ \\
\hline 2. & $\begin{array}{l}\text { Peptidoglycan recognition } \\
\text { protein (PRP) }\end{array}$ & $\begin{array}{l}\text { Stimulates immune response and has } \\
\text { antimicrobial activity }\end{array}$ & El Agamy et al., 1992 \\
\hline 3 & Lactoferrin & $\begin{array}{l}\text { Prevents pathogenic invasion and microbial } \\
\text { overgrowth }\end{array}$ & $\begin{array}{l}\text { El Agamy et al., 1992; } \\
\text { Konuspayeva et al., } 2006\end{array}$ \\
\hline 4 & Lactoperoxidase & $\begin{array}{l}\text { Antitumor activity } \\
\text { Antibacterial against gram negative bacteria } \\
\text { like E. Coli, Salmonella and Pseudomonas } \\
\text { Bacteriostatic against gram positive }\end{array}$ & El Agamy et al., 1996 \\
\hline 5 & Lysozyme & Targets Gram positive bacteria & El Agamy et al., 1992 \\
\hline 6. & $\mathrm{~N}$-acetyl-glucosamineidase (NAGase) & Antibacterial and antiviral activity & Jassim and Naji, 2001 \\
\hline
\end{tabular}

efficient refolding after chemical or thermal denaturation. To a lesser extent, an increased resistance against denaturation may be responsible for it (Maliheh et al., 2011).

\section{Special features of camelid antibodies}

Structurally, a classical antibody present in mammals consists of two heavy and two light chains interconnected by disulfide bonds. The antibodies present in humans and most other mammalian species are essentially Y-shaped proteins which have a vital role in various antigen-elimination mechanisms and also act against cancer. The classical antibody contains an $\mathrm{N}$-linked oligosaccharide attached to the second heavy-chain constant domain (CH2) that is essential for antibody effector functions such as antibody-dependent cellular cytotoxicity (ADCC), complement-dependent cytolysis (CDC), and for retaining a long serum half-life. Even after isolation, the heavy (Utsumi and Karush, 1964) and light chains (Yoo et al., 1967) of an antibody can retain their antigen binding specificity; however reduction in their affinity and solubility is often observed (Ward et al., 1989).

Camelids (Bactrian and dromedaries camels, as well as llamas) generate antibodies devoid of light chains (Hamers-Casterman et al., 1993). The single N-terminal domain of these heavy chain antibodies is fully capable of binding with the antigen.

Another specialty of these antibodies is that they lack the $\mathrm{CH} 1$ domain, which remains associated with the light chain as well as to some extent with the $\mathrm{V}_{\mathrm{H}}$ domain, in case of classical antibodies. Besides these special antibodies, camelids also have the normal type of mammalian antibodies. The affinities of VHHs are generally comparable to those of conventional antibody fragments (Maliheh et al., 2011). Dedicated Immunoglobulin Heavy chain genes are used to produce heavy chain antibodies in camels. Similar to conventional antibody genes, the dromedary genes have identity in the organization of relevant regions such as exons and introns of the immunoglobulins (Muyldermans, 2013).

The sequence study (Hamers-Casterman et al., 1993) and revelation of crystal structure (Desmyter et al., 2001; Spinelli et al., 1996) have exposed various structural characteristics of $\mathrm{VHH}$ domains of camelid antibodies. The structural organization of VHH domains consist of four framework regions (FRs) which together form the core structural configuration of the immunoglobulin and three Complementarity Determining Regions (CDRs) that are involved in the interaction with antigen. The $\mathrm{V}_{\mathrm{H}}$ domains of classical antibodies contain conserved amino acid sequences at positions 37, 44, 45, and 47 (Kabat numbering) of FR2. These amino acids are responsible for the hydrophobic interaction of $\mathrm{V}_{\mathrm{H}}$ domains with the $\mathrm{V}_{\mathrm{I}}$ domains. However VHHs have substituted amino acids at the above four mentioned FR2 positions due to which they attain an increased hydrophilic character. Also some of the amino acids at positions forming hydrophobic patch in classical antibody's $\mathrm{V}_{\mathrm{H}}$ domain contacting $\mathrm{CH} 1$ (Lesk and Chothia, 1988) are also replaced by hydrophilic residues in VHHs. Additional features are also present in case of CDRs of VHHs which includes the increased variability of N-terminal part of CDR1 (Vu et al., 1997; Harmsen et al., 2000; Nguyen et al., 2000) and an extended CDR3 in case of many dromedary VHHs which is often stabilized by an extra disulfide bond in CDR1 or FR2 (Muyldermans et al., 1994).

In comparison to classical antibodies, the VHHs are more stable at higher temperatures. VHHs remain functional even at $90^{\circ} \mathrm{C}$ or even when subjected to incubation at high temperatures (Van der Linden et al., 1999). The efficient refolding of VHHs after chemical or thermal denaturation provides them with enhanced stability and to some extent is also attained because of their increased resistance to denaturation (Dumoulin et al., 2002; 
Ewert et al., 2002). Additionally the refolding of VHHs involve only domain refolding while in case of classical antibodies, interaction between $\mathrm{V}_{\mathrm{H}}$ and $\mathrm{V}_{\mathrm{L}}$ domains is also required.

VHHs can even recognize antigenic sites that are normally not recognized by classical antibodies, for instance the active sites of enzymes (Lauwereys et al., 1998; De Genst et al., 2006) and conserved cryptic epitopes (Stijlemans et al., 2004). Hence the VHHs can be utilized as enzyme inhibitors. The smaller size of VHHs gives them an added advantage to access and recognize hidden antigenic sites. Even their extended CDR3 loop has the ability to penetrate and access such sites (Desmyter et al., 1996; De Genst et al., 2006).

The smaller size of VHHs (12-15 kDa) as compared to common antibodies (150-160kDa), allows them to rapidly pass the renal filter, which has cutoff of around $60 \mathrm{kDa}$, thereby facilitating their rapid blood clearance. In addition to this the small size also aids in quick tissue penetration which can be used for targeting tumors by VHHs coupled to cytotoxic drugs (Cortez-Retamozo et al., 2004). VHH coupled tumor targeting can be used for in vivo diagnosis in association with imaging techniques. Furthermore, it can even be used in the treatment of snake bites (Harrison et al., 2006).

\section{Anticancer properties of camel milk}

Middle Eastern countries have traditionally used camel milk for therapeutic benefits against cancer. There are upcoming clear cut indications suggesting the potential role of camel milk against cancer.

\section{Evidences supporting anti-cancer properties of camel milk}

An epidemiological survey was conducted to study the prevalence of diabetes in a local Nomadic community called Raika (Agrawal et al., 2007). This community is totally dependent on camel milk for its day to day needs. During his entire study he did not come across a single case of cancer (personal communication). The low prevalence of cancer in communities consuming camel milk is indeed remarkable. Recently, Korashy et al., in 2012 have reported that camel milk has the ability to significantly inhibit the induction of the Cyp1A1, a cancer-activating gene. Further it also induces NQO1, a cancer chemo preventive gene in murine hepatoma Hepa 1c1c7 cells. Both these functions were studied at the transcriptional and posttranscriptional level. It was observed that the survival of HepG2 cells was significantly reduced upon incubation with camel milk. Further, they observed that camel milk significantly induced caspase-3 and DR4 mRNA expression levels. The induction of Casepase-3 was blocked by the action of Act-D. This indicates that camel milk increased the caspase- $3 \mathrm{mRNA}$ level by the de novo synthesis of RNA. It was further observed that pretreatment of cells with MAPK inhibitors alone, slightly, but not significantly decreased the basal expression level of caspase- 3 mRNA. Furthermore, it was reported that the induction of caspase $3 \mathrm{mRNA}$ by camel milk in HepG2 cells was significantly decreased by both the JNK and p38 MAPKs inhibitors and was potentiated by an ERK inhibitor.

Mohamed E.M. Afifi (2010) studied the protective effect of camel milk against cisplatin-induced renal oxidative stress in mice. Cisplatin induced stress was indicated by increased level of liver tissue metabolites such as malondialdehyde, serum creatinine and urea. This stress also led to a decrease in the concentration of glutathione, vitamin $\mathrm{C}$ and $\mathrm{E}$. At an enzymatic level cisplatin decreased both, the activity and gene expression of superoxide-dismutase, catalase glutathione reductase and glutathione peroxidase. In their study, treatment of these animals significantly increased the level of malondialdehyde as well as the enzymes viz. superoxidedismutase, catalase, glutathione reductase and glutathione peroxidase. The increase caused in catalase was not significant. The camel milk caused reduction in all these biochemical alterations and counteracted the deleterious effects of cisplatin. This study demonstrated the renoprotective potential of camel's milk against cisplatin-induced oxidative stress.

Alpha-lactalbumin upon combination with oleic acid can be converted to the complex, HAMLET, which kills tumor cells selectively. The thermal stability of camel milk $\alpha$-lactalbumin and its complexes with oleic acid and linoleic acid were studied at $60^{\circ} \mathrm{C}$. Both these complexes were observed to have a stable structure. They were able to exhibit a cytotoxic effect on DU145, a human prostate cancer cell line, even after exposure to temperatures as high as $60^{\circ} \mathrm{C}$ (Maliheh et al., 2011).

\section{Mechanism of action of camel milk proteins}

Camel milk components act as a ligand to the aryl hydrocarbon receptor (AhR). Signaling via aryl hydrocarbon receptor has a definite anticancer action. This receptor is an endogenous transcription factor known to have a preventive as well as therapeutic benefit to patients with cancers of breast, liver, prostate, etc. (Zhang et al., 2009).

\section{Role of aryl hydrocarbon receptors}

Aryl hydrocarbon receptor (AhR) is a basichelix-loop-helix (bHLH)/Per-ARNT-Sim (PAS) family of transcription factor which is found in the cytosol and is activated after binding with its ligand. This family of transcription factors regulates the pathways involved in cellular proliferation and differentiation (Kerzeeand Ramos, 2001; Whitelaw et al., 1993). In the cytosol, AhR remains 
as an inactive complex when bound with Heat Shock Protein-90 (HSP90) and AhR interacting protein (AIP). The interaction of $\mathrm{AhR}$ with its ligands, such as 2,3,7,8-tetrachlorodibenzo-p-dioxin (TCDD), a polycyclic aromatic hydrocarbon $(\mathrm{PAH})$, results in the dissociation of bound HSP90 and AIP and hence its activation. This subsequently leads to its translocation into the nucleus. After entering the nucleus it forms a dimer by interacting with the AhR nuclear translocator (ARNT) and then proceeds to bind with xenobiotic-responsive element (XRE) found in the promoter region of the so called AhR regulated genes. It's binding results in the transcription and translation of these genes (Whitlock, 1999; Nebert et al., 2000). The group of genes regulated by AhR includes both phase I xenobiotic metabolizing enzymes such as the cytochrome P4501A1 (C-YP1A1), CYP1A2, CYP1B1 and phase II enzymes such as NAD (P) H: quinone-oxidoreductase 1 (NQO1), Glutathione S-transferase A1 (GSTA1), Uridine diphosphate glucuronosyl-transferase1A6, and Aldehyde dehydrogenase-3 (Whitlock, 1999; Nebert et al., 2000). Among the above mentioned genes, CYP1A1 is considered a cancer activating gene as it plays an important role in the bioactivation of procarcinogens into carcinogens and other toxic metabolites (Nebert et al., 2004). On the other hand, NQO1 and GSTA1 catalyze the reduction of numerous environmental contaminants and also maintain the optimum level of endogenous antioxidants like vitamin $\mathrm{E}$ and ubiquinone. This helps in protecting the tissues against mutagens, carcinogens and damages induced by oxidative stress (Ross, 2004; Vasiliou et al., 2006).

\section{Modulation of aryl hydrocarbon receptors in cancer therapy}

Several lines of evidence have shown that the induction ofCYP1A1 strongly correlates with increased incidences of human colon, rectal, and lung cancers (Slattery et al., 2004; Shah et al., 2009). In addition, studies on carcinogenicity and mutagenicity of PAHs have demonstrated a significant role in induction of CYP1A1 in bioactivating these environmental toxicants into their ultimate carcinogenic forms (Shimada and Fujii-Kuriyama, 2004). Thus, CYP1A1 induction is considered a useful biomarker of exposure to carcinogenic substances (Williams et al., 2000).

Accordingly, one of the strategies for protecting human cells and tissues from the toxic effects of carcinogenic and cytotoxic metabolites is to attenuate the carcinogen-activating genes, CYP1A1 signaling pathways, and/or enhancing the adaptive mechanisms by increasing the expression of detoxification and antioxidant genes, such asNQO1 and GSTA1. Therefore camel milk can be postulated to protect against or decrease the deleterious effects of many environmental toxicants and carcinogens such as PAHs, probably through modulation of AhR-regulated genes, such as CYP1A1, NQO1, and GSTA1 at the transcriptional and post transcriptional level.

Aberrant aryl hydrocarbon receptor expression and the activation of AhR pathway is involved in carcinogenesis. Exogenous AhR agonists promote differentiation in a putative mammary cancer stem cell line. Moreover, activation of the AhR is known to inhibit invasive and metastatic features of human breast cancer cells (Zhang et al., 2009). It has been shown that the aryl hydrocarbon receptor functions as a suppressor of liver carcinogenesis. It has also been observed that AhR pathway activation enhances gastric cancer cell invasiveness through a c-Jun-dependent induction of matrix metalloproteinase-9.

New antitumor drugs like aminoflavone and benzothiazoles, require AhR-mediated signaling to expedite DNA damage. These drugs show antitumor activity in the estrogen receptor of positive breast cancer cell line, MCF-7. However, nude mice model having estrogen receptor negative breast cancer cells like MDA-MB-231 is less susceptible to the action of these drugs. This study indicates that these drugs, unlike other neoplastic agents, require AhR-mediated signaling to cause DNA damage. This is a new treatment strategy for breast cancers cells which have intact AhR signaling mechanisms. Camel milk constituents are known to similarly act through aryl hydrocarbon receptors (Callero and Loiaza-Perez, 2011).

\section{CONCLUSION}

Evolutionary pressures have played a vital role in accrediting milk with very significant immunological and anti-cancer properties. Camel has specially evolved to adapt under stressful conditions. As a result of these adaptations, it has an extraordinary immune system containing special feature antibodies. Camel milk proteins are thermostable and acid hydrolysis resistant, thus very relevant. Camel milk is known to contain many compounds that exhibit anti-cancer properties in other mammalian species. It is therefore immensely important to understand these special attributes to fully utilize the potential of camel milk. The future prospect includes utilization of camel milk as a nutraceutical agent with adjunct therapeutic potential.

\section{Author contribution}

All authors contributed equally in this article.

\section{REFERENCES}

Agrawal, R. P., S. C. Swami, R. Beniwal, D. K. Kochar and R. P. Kothari. 2002. Effect of camel milk on glycemic control, risk factors and diabetes quality of life in type-1 diabetes: A randomized prospective controlled study. Int. Diabetes Dev. Ctries. 22: 70-74. 
Agrawal, R. P., S. C. Swami, R. Beniwal, D. K. Kochar and M. S. Sahani. 2003. Effect of camel milk on glycemic control, lipid profile and diabetes quality of life in type 1 diabetes: A randomized prospective controlled cross over study. Indian J. Anim. Sci. 73: 1105-1110.

Agrawal, R. P., R. Beniwal, D. K. Kochar, F. C. Tuteja and S. K. Ghorui. 2005. Camel milk as an adjunct to insulin therapy improves long-term glycemic control and reduction in doses of insulin in patients with type-1 diabetes A 1 year randomized controlled trial. Diabetes Res. Clin. Pract. 68: 176-177.

Agrawal, R. P., S. Budania, P. Sharma, R. Gupta and D. K. Kochar. 2007. Zero prevalence of diabetes in camel milk consuming Raica community of northwest Rajasthan, India. India Diabetes Res. Clin. Pract. 76: 290-296.

Agrawal, R. P., P. Tantia, S. Jain, R. Agrawal and V. Agrawal. 2013. Camel milk: A possible boon for Type I diabetic patients. Cell. Mol. Biol. 59: 99-107.

Ahmed, A. S., N. H. Abdalbagi, H. A. Mustafa, A. A. A. Idris, A. M. A. Ismail and R. Eltayb. 2011. The role of camel milk in the reactivation of liver damaged by Sudanese liquor (Aragi). J. Public Health. 6: 157-163.

Aits, S., L.Gustafsson, O. Hallgren, P. Brest, M. Gustafsson, M. Trulsson, A. K. Mossberg, H. U. Simon, B. Mograbi and C. Svanborg. 2009. HAMLET (human alpha-lactalbumin made lethal to tumor cells) triggers autophagic tumor cell death. Int. J. Can. 124: 1008-1019.

Al-Fartosi, K. G., O. S. Khuon and H. I. Al-Tae. 2011. Protective role of camel's milk against paracetamol induced hepatotoxicity in male rats. Int. J. Res. Pharm. Biomed. Sci. 2: 1795-1799.

Amarù, D. L. and C. J. Field. 2009. Conjugated linoleic acid decreases MCF-7 human breast cancer cell growth and insulin-like growth factor-1 receptor levels. Lipids. 26: 449-458.

Aungst, B. J. 2000. Intestinal permeation enhancers. J. Pharmaceut. Sci. 89: 429-442.

Baubekova, A., S. A. Kalimbetovaa, S. Akhmetsadykova, G. Konuspayeva and B. Faye. 2015. Comparison of D-lactate and L-lactate content in cow and camel milk. In: Proceedings of 4th Conference of ISOCARD 'Silk Road Camel: The Camelids, Main Stakes For Sustainable Development'. Publisher Special Issue of Scientific and Practical Journal Veterinariya \#2 (42) 2015, Almaty, Kazakhstan. Pp. 397-398.

Beg, O. U., H. V. Bahr-Lind, Z. H. Zaidid and H. Jhornvall. 1986. Characterization of a camel milk protein rich in proline identifies a new beta-casein fragment. Regul. Pept. 15: 55-61.

Behrens, I., A. I. V. Pena, M. J. Alonso and T. Kissel. 2002. Comparative uptake studies of bioadhesive and non-bioadhesive nanoparticles in human intestinal cell lines and rats: the effect of mucus on particle adsorption and transport. Pharm. Res. 19: 1185-1193.

Bray, F., J. S. Ren, E. Masuyerand and J. Ferlay. 2013. Estimates of global cancer prevalence for 27 sites in the adult population in 2008. Int. J. Can. 132: 1133-1145.

Brest, P., M. Gustafsson, A. K. Mossberg, L. Gustafsson, C. Duringer, A. Hamiche and C. Savanborg. 2007. Histone deacetylase inhibitors promote thetumoricidal effect of HAMLET. Cancer Res. 67: 11327-11334.

Callero, M. A. and A. I. Loaiza-Pérez. 2011. The role of aryl hydrocarbon receptor and crosstalk with estrogen receptor in response of breast cancer cells to the novel antitumor agents benzothiazoles and aminoflavone. Int. J. Br. Can. Article ID 923250. Available from: http://www.dx.doi.org/10.4061/2011/923250.

Conesa, C., L. Sanchez, C. Rota, M. D. Pérez, M. Calvo, S. Farnaud and R. W. Ewans. 2008. Isolation of lactoferrin from milk of different species: Calorimetric and antimicrobial studies. Comp. Biochem. Physiol. Part B. 150: 131-139.

Cardoso, R. A., R. M. D. B. Santos, C. R. A. Cardoso and M. O. Carvalho. 2010.Consumption of camel's milk by patients intolerant to lactose. A preliminary study. Rev. Alergia México. 57: 26-32.

Cortez, R. V., M. Lauwereys, G. G. Hassanzadeh, M. Gobert, K. Conrath, S. Muyldermans, D. P. Baetselier and H. Revets. 2002. Efficient tumor targeting by single-domain antibody fragments of camels. Int. J. Cancer. 98: 456-462.

Cortez-Retamozo, V., N. Backmann, P. D. Senter, U. Wernery, P. De-Baetselier, S. Muyldermans and H. Revets. 2004. Efficient cancer therapy with a nanobody-based conjugate. Cancer Res. 64: 2853-2857.

Davanzo, R., G. Zauli, M. Lorenzo, L. V. Brumatti, M. V. Abate, G. Ventura, E. Rimondi, P. Secchiero and S. Demarini. 2012. Human colostrum and breast milk contain high levels of TNFRelated Apoptosis-Inducing Ligand (TRAIL). J. Hum. Lact. 29: 23-25.

Davis, M. K. 1998. Review of the evidence for an association between infant feeding and childhood cancer. Int. J. Cancer. Suppl 11: 29-33.

De Genst, E., K. Silence, K. Decanniere, K. Conrath, R. Loris, J. Kinne, S. Muyldermans and L. Wyns. 2006. Molecularbasis for the preferential cleft recognition by dromedary heavy-chain antibodies. Proc. Nat. Acad Sci. USA. 103: 4586-4591.

Desmyter, A., T. R. Transue, M. A. Ghahroudi, M. H. Thi, F. Poortmans, R. Hamers, S. Muyldermans and L. Wyns. 1996. Crystal structure of a camelsingle-domain $\mathrm{VH}$ antibody fragment in complex with lysozyme. Nat. Struct. Mol. Biol. 3: 803-811.

Desmyter, A., K. Decanniere, S. Muyldermans and L. Wyns. 2001. Antigen specificity and high affinity binding provided by one single loop of a camel single-domain antibody. J. Biol. Chem. 276: 26285-26290.

Dumoulin, M., K. Conrath, A. Van Meirhaeghe, F. Meersman, K. Heremans, L. G. Frenken, S. Muyldermans, L. Wyns and A. Matagne. 2002. Single-domain antibody fragments with high conformational stability. Prot. Sci. 11: 500-515.

Duringer, C., A. Hamiche, L. Gustafsson, H. Kimura and C. Svanborg. 2003. HAMLET interacts with histones and chromatin in tumor cell nuclei. J. Biol. Chem. 278: 42131-42135.

El-Agamy, E. I., R. Ruppanner, A. Ismail, C. P. Champagne and R. Assaf. 1992. Antibacterial and antiviral activity of camel milk protective proteins. J. Diary Res. 59: 169-175.

El-Agamy, E. I., R. Ruppanne, A. Ismail, C. P. Champagne and R. Assaf. 1996. Purification and characterization of lactoferrin, lactoperoxidase, lysozyme and immunoglobulins from camel's milk. Int. Dairy J. 6: 129-145.

El-Agamy, E. I., M. Nawar, S. M. Shamsia, S. Awad and G. F. W. Haenlein. 2009. Are camel milk proteins convenient to the nutrition of cow milk allergic children? Small Rumin. Res. 82: 1-6.

El-Fakharany, E. M., A. Tabll, A. A. E. Wahahb, B. M. Haroun and E. R. M. Redwan. 2008. Potential activity of camel milk-amylase and lactoferrin against hepatitis c virus infectivity in hepG2 and lymphocytes. Hepat. Mon. 8: 101-109.

Ewert, S., S. Cambillau, K. Conrath and A. Pluckthun. 2002. Biophysical properties of camelid $\mathrm{V}(\mathrm{HH})$ domains compared to those of human $\mathrm{V}(\mathrm{H}) 3$ domains. Biochemistry. 41: 36283636.

GLOBOCAN. 2012. (IARC), Section of Cancer Surveillance (8/10/2014); Available from: http://www.globocan.iarc.fr/Pages/ fact_sheets_cancer.aspx. 
Faye, B. 2014. Anatomical and physiological adaptation of domestic animals to ecosystem constraints: the example of the camel in arid lands. Bull. Al-Farabi Univ. Sériebiol. 1/2. 60: 134-137.

Faye, B., M. Bengoumi, A. Al-Masaud and G. Konuspayeva. 2015. Comparative milk and serum cholesterol content in dairy cow and camel. J. King Saud. Univ. Sci. 27: 168-175.

Fischer, W., L. Gustafsson, A. K. Mossberg, J. Gronli, S. Mork, R. Bjerkvig and C. Svanborg. 2004. Human alpha-lactalbumin made lethal to tumor cells (HAMLET) kills human glioblastoma cells in brain xenografts by an apoptosis-like mechanism and prolongs survival. Cancer Res. 64: 2105-2112.

Goldsby, R. A., J. K. Kindt, B. A. Osborne and J. Kuby. 2003. Antibodies: Structure and Function. Immunology. $5^{\text {th }}$ ed. W. H. Freeman and Company, New York, Pp. 76-104.

Gullberg, E. 2005. Particle Transcytosis Across the Human Intestinal Epithelial. Ph.D. Thesis, Uppsala University, Sweden. Available from: http://www.diva-portal.org/smash/get/diva2:165733/ FULLTEXT01.pdf.

Gustafsson, L., S. Aits, P. Onnerfjord, M. Trulsson, P. Storm and C. Svanborg. 2009. Changes in proteosome structure and function caused by HAMLET in tumor cells. PLos One. 4: e5229.

Hakansson, A., B. Zhivotovsky, S. Orrenius, H. Sabharwal and C. Svanborg. 1995. Apoptosis induced by a human milk protein. Proc. Natl. Acad. Sci. U.S.A. 92: 8064-8068.

Hamad, E.M., E. A. Abdel-Rahim and E. A. Romeih. 2011. Beneficial effect of camel milk on liver and kidneys function in diabetic sprague-dawley rats. Int. J. Dairy Sci. 6: 190-197.

Hamers-Casterman, C., T. Atarhouch, S. Muyldermans, G. Robinson, C. Hamers, E. B. Songa, N. Bendahman and R. Hamers. 1993. Naturally occurring antibodies devoid of light chains. Nat. 363: 446-448.

Harmsen, M. M., R. C. Ruuls, I. J. Nijman, T. A. Niewold, L. G. J. Frenkenand and B. deGeus. 2000. Llama heavy-chain $V$ regions consist of at least four distinct subfamilies revealing novel sequence features. Mol. Immunol. 37: 579-590.

Harmsen, M. M. and H. J. De Haard. 2007. Properties, production and applications of camelid single-domain antibody fragments. Appl. Microbiol. Biotechnol. 77: 13-22.

Han, S., F. R. Khuri and J. Roman. 2006. Fibronectin stimulates nonsmall cell lung carcinoma cell growth through activation of Akt/ mammalian target of rapamycin/S6 kinase and inactivation of LKB1/AMP activated protein kinase signal pathways. Cancer Res. 66: 315-323.

Harrison, R. A., S. S. Hasson, M. Harmsen, G. D. Laing, K. Conrath and R. D. Theakston. 2006. Neutralization of venom-induced hemorrhage by $\mathrm{lgG}$ from camels and llamas immunized with viper venom and also by endogenous, non-lgG components in camelid sera. Toxicon. 47: 364-368.

Harikrishnan, K. K. 2006. The Milk Tale in Ayurveda. Punarnava Ayurveda. Arogyadham Ayurvedic Hospital. Palakkad, India. Pp. $1-22$

Hejazi, R. and M. Amiji. 2003. Chitosan-based gastrointestinal delivery systems. J. Control. Release. 89: 151-165.

Horinaka, M., T. Yoshida, A. Kishi, K. Akatani, T. Yasuda, J. Kouhara, M. Wakada and T. Sakai. 2010. Lactobacillus strains induce TRAIL production and facilitate natural killer activity against cancer cells. Fed. Eu. Biochem. Soc. (FEBS) Lett. 584: 577-582.

Jadambaa, S., T. S. Batsuh and P. Baigalmaa. 2000. Research on use of camel milk to treat liver diseases. Prod. Technical. Univ. 8: 17-21.

Jassim, S. A. A. and M. A. Naji. 2001. Camel immune system and activity of milk. Biologist. 48: 268-272.
Kerzee, J. K. and K. S. Ramos. 2001. Constitutive and inducible expression of Cyp1a1 and Cyp1b1 in vascular smooth muscle cells: role of the AhrbHLH/PAS transcription factor. Circ. Res. 89: 573-582.

Kontou, N., T. Psaltopoulou, D. Panagiotakos, M. A. Dimopoulos, and A. Linos. (2011). The mediterranean diet in cancer prevention: A review. J. Med. Food. 14: 1065-1078.

Konuspayeva, G., B. Faye, G. Loisea and D. Levieux. 2006. Lactoferrin and immunoglobin content in camel milk from Kazakhstan. J. Dairy Sci. 90: 38-46.

Konuspayeva, G., E. Lemarie, B. Faye, G. Loiseau and D. Montet. 2008. Fatty acid and cholesterol composition of camel's (Camelus bactrianus, Camelus dromedarius and hybrids) milk in Kazakhstan. Dairy Sci. Technol. 88: 327-340.

Konuspayeva, G., B. Faye and G. Loiseau. 2009. The composition of camel milk: A meta-analysis of the literature data. J. Food Comp. Anal. 22: 95-101.

Konuspayeva, G., B. Faye and L. Loiseau. 2011. Variability of vitamin C content in camel milk from Kazakhstan. J. Camelid Sci. 4: 6369.

Korashy, H. M., Z. H. Maayah, A. R. El-Kadi and A. A. Alhaider. 2012a. Camel milk triggers apoptotic signaling pathways in human hepatoma hepG2 and breast cancer MCF7 cell lines through transcriptional mechanism. J. Biomed. Biotechnol. 2012: Article ID: 593195. DOI: 10.1155/2012/593195.

Korashy, H. M., M. A. M. El-Gendy, A. A. Al-haider and A. O. El-Kadi. 2012b. Camel milk modulates the expression of aryl hydrocarbon receptor regulated genes, Cyp1a1, Nqo1, andGsta1, in Murine hepatomaHepa 1c1c7 Cells. J. Biomed. Biotech. 2012: Article ID: 782642. DOI: 10.1155/2012/782642.

Laskowski, M. Jr., H. A. Haessler, R. P. Miech, R. J. Peanasky and M. Laskowski. 1958. Effect of trypsin inhibitor on passage of insulin across the intestinal barrier. Sci. 127: 1115-1116.

Lauwereys, M., A. M. Ghahroudi, A. Desmyter, J. Kinne, W. Holzer, E. De Genst, L. Wyns and S. Muyldermans. 1998. Potent enzyme inhibitors derived from dromedary heavy-chain antibodies. Eur. Mol. Biol. Org. J. 17: 3512-3520.

LeCluyse, E. L. and S. C. Sutton. 1997. In vitro models for selectionof development candidates. Permeability studies to define mechanisms of absorption enhancement. Adv. Drug Deliv. Rev. 23: 163-183.

Lesk, A. M. and C. Chothia. 1988. Elbow motion in the immunoglobulins involves a molecular ball-and-socket joint. Nat. 335: 188-190.

Magjeed, N. A. 2005. Corrective effect of camel milk on some cancer biomarkers in blood of rats intoxicated with alpha Flatoxin B1. J. Saud. Chem. Soc. 9: 253-263.

Maliheh S. A., A. A. Saboury, A. A. M. Movahedi, B. Goliaei, Y. Sefidbakht, H. H. Alijanvand, A. Sharifzadeh and A. N. Naslaji. 2011. Structure and stability analysis of cytotoxic complex of camel $\alpha$-lactalbumin and unsaturated fatty acids produced at high temperature. J. Biomol. Struct. Dynamic. 28: 919-928.

Mathur, G. P., N. Gupta, S. Mathur, V. Gupta, S. Pradhan, J. N. Dwivedi, B. N. Tripathi, K. P. Kushwaha, N. Sathy and U. J. Modi. 1993. Breastfeeding and childhood cancer. Indian Pediatr. 30: 651-657.

Mohamed, E. M. A. 2010. Effect of camel's milk on cisplatin-induced nephrotoxicity in Swiss Albino mice. Am. J. Biochem. Biotech. 6: 141-147.

Mossberg, A. K., B. Wullt, L. Gustafsson, W. Mansson, E. Ljunggren and C. Svanborg. 2007. Bladder cancers respond to intravesical instillation of HAMLET (human a-lactalbumin made lethal to tumor cells). Int. J. Cancer. 121: 1352-1359. 
Mossberg, A. K., M. Puchades, O. Halskau, A. Baumann, I. Lanekoff, I. Chao, A. Martinez and C. Svanborg. 2010. HAMLET interacts with lipid membranes and perturbs their structure and integrity. PLoS One. 5: e9384.

Muyldermans, S. 2013. Nanobodies: Natural single-domain antibodies. Ann. Rev. Biochem. 82: 17.1-17.23.

Muyldermans, S., T. Atarhouch, J. Saldanha, J. A. Barbosa and R. Hamers. 1994. Sequence and structure of VH domain from naturally occurring camel heavy chain immunoglobulins lacking light chains. Prot. Eng. 7: 1129-1135.

Nebert, D. W., A. L. Roe, M. Z. Dieter, W. A. Solis, Y. Yang and T. P. Dalton. 2000. Role of the aromatic hydrocarbon receptor and [Ah] gene battery in the oxidative stress response, cell cycle control and apoptosis. Biochem. Pharm. 59: 65-85.

Nebert, D. W., T. P. Dalton, A. B. Okey and F. J. Gonzalez. 2004. Role of aryl hydrocarbon receptor-mediated induction of the CYP1 enzymes in environmental toxicity and cancer. J. Biol. Chem. 279: 23847-23850.

Nguyen, V. K., R. Hamers, L. Wyns and S. Muyldermans. 2000. Camel heavy-chain antibodies: diverse germline $\mathrm{V}(\mathrm{H}) \mathrm{H}$ and specific mechanisms enlarge the antigen-binding repertoire. Eur. Mol. Biol. Org. J. 19: 921-930.

Nikkhah, A. 2011. Science of camel and yak milks: Human nutrition and health perspectives. Food Nutr. Sci. 2: 667-673.

Newman, J. 1995. How breast milk protects newborns. Sci. Am. 273: 76-79.

Okada, J., S. Cohen and R. Langer.1998. Oral Delivery of Vaccines Using Polymerized Liposomes, in US Patent 5762, 904.

Parodi, P. W. 2007. A role for milk proteins and their peptides in cancer prevention. Curr. Pharm. Des. 13: 813-828.

Peppas, N. A. 2004. Devices based on intelligent biopolymers for oral protein delivery. Int. J. Pharm. 277: 11-17.

Riad, F., M. Bengoumi, M. J. Davicco, A. Safwate and J. P. Barlet. 1994. Influence of 1-alfa hydroxycholecalciferol on calcium and phosphorus concentration in camel milk. J. Dairy Res. 61: 567571.

Ross, D. 2004. Quinone reductases multitasking in the metabolic world. Drug Met. Rev. 36: 639-654.

Shabo, Y., R. Barzel, M. Margoulis and R. Yagil. 2005. Camel Milk for food allergies in children. Immunol. Allergy. 7: 796-798.

Shah, P. P., K. Saurabh, M. C. Pant, N. Mathur and D. Parmar. 2009. Evidence for increased cytochrome P450 1A1 expression in blood lymphocytes of lung cancer patients. Mut. Res. Fundament. Mol. Mech. Mutagenesis. 670: 74-78.

Shamsia, S. M. 2009. Nutritional and therapeutic properties of camel and human milks. Int. J. Gen. Mol. Biol. 1: 52-58.

Sharmanov, T. S. and R. D. Kadyrova. 1978. Changes in the indicators of radioactive isotope studies of the liver of patients with chronic hepatitis during treatment with whole camels' milk and mares' milk. Voprosy Pytaniya. 1: 9-13.

Shimada, T. and Y. Fujii-Kuriyama. 2004. Metabolic activation of polycyclic aromatic hydrocarbons to carcinogens by cytochromes P450 1A1 and 1B1. Cancer Sci. 95: 1-6.

Singh, R. 2001. Annual Report of National Research Centre on Camel, Bikaner, India.

Singh, R., S. Singh and J. W. Lillard. 2008. Past, present and future technologies for oral delivery of therapeutic proteins. J. Pharm. Sci. 97: 249-2523.

Singh, S., A. Suryawanshi, Y. M. Joshi, D. Limaye and V. Kadam. 2012. Human milk execellent anticancer alternative. Int. J. Res. Pharm. Chem. 5: 14-19.
Slattery, M. L., W. Samowtiz, K. Ma, M. Murtaugh, C. Sweeney, T. R Levin and S. Neuhausen. 2004. CYP1A1, cigarette smoking, and colon and rectal cancer. Am. J. Epidemiol. 160: 842-852.

Spinelli, S., L. Frenken, D. Bourgeois, L. de Ron, W. Bos, T. Verrips, C. Anguille, C. Cambillau and M. Tegoni. 1996. The crystal structure of a llama heavy chain variable domain. Nat Struct. Mol. Biol. 3: 752-757.

Spolaore, B., O. Pinato, M. Canton, M. Zambonin, P. P. Laureto and A. Fontana. 2010. a-Lactalbumin forms with oleic acid a high molecular weight complex displaying cytotoxic activity. Biochemistry. 49: 8658-8667.

Stijlemans, B., K. Conrath, V. Cortez-Retamozo, H. Van Xong, L. Wyns, P. Senter, H. Revets, P. De Baetselier, S. Muyldermans and S. Magez. 2004. Efficient targeting of conserved cryptic epitopes of infectious agents by single domain antibodies. Afr. Trypanosomes as paradigm. J. Biol. Chem. 279: 1256-1261.

Svensson, M., A. Håkansson, A. K. Mossberg, S. Linseand C. Svanborg. 2000. Conversion of $\alpha$-Lactalbumin to a protein inducing apoptosis. Proc. Nat. Acad. Sci. 97: 4221-4226.

Trulsson, M., H. Yu, L. Gisselsson, Y. Chao, A. Urbano, S. Atis, A. K. Mossberg and C. Svanborg. 2011. HAMLET binding to alphaactinin facilitates tumor cell detachment. PLoS One. 6: e17179.

Utsumi, S. and F. Karush. 1964. The subunits of purified rabbit antibody. Biochemistry. 3: 1329-1338.

Van der Linden, R. H., L. G. Frenken, B. De Geus, M. M. Harmsen, R. C. Ruuls, W. Stok, L. De Ron, S. Wilson, P. Davis and C. T. Verrips. 1999. Comparison of physical chemical properties of llama $\mathrm{VHH}$ antibody fragments and mouse monoclonal antibodies. Biochim. Biophys. Acta. 1431: 37-46.

Vasiliou, V., D. Ross and D. W. Nebert. 2006. Update of the NAD(P) $\mathrm{H}$ : Quinoneoxidoreductase (NQO) gene family. Hum. Genom. 2: 329-335.

Vu, K. B., M. A. Ghahroudi, L. Wyn and S. Muyldermans. 1997. Comparison of llama VH sequences from conventional and heavy chain antibodies. Mol. Immunol. 34: 1121-1131.

Wangoh, J., Z. Farah and Z. Puhan. 1998. Composition of milk from three Camel (Camelus dromedarius) breeds in Kenya during lactation. Milchwissenschaft. 53: 136-139.

Ward, E. S., D. Gussow, A. D. Griffiths, P. T. Jones and G. Winter. 1989. Binding activities of a repertoire of single immunoglobulin variable domains secreted from Escherichia coli. Nature. 341: 544-546.

Watanabe, Y. 2004. Fifty years of interference. Nat. Immunol. 5: 1193.

Whitelaw, M., I. Pongratz, A. Wilhelmsson, J. S. A. A. Gustafsson and L. Poellinger. 1993. Ligand-dependent recruitment of the arntcoregulator determines DNA recognition by the dioxin receptor. Mol. Cell. Biol. 13: 2504-2514.

Whitlock, J. P. Jr. 1999. Induction of cytochrome P4501A1. Ann. Rev. Pharm. Toxicol. 39: 103-125.

Williams, T. S., J. S. Lee, D. L. Sheader and J. K. Chipman. 2000. The cytochrome P450 1A gene (CYP1A) from European flounder (Platichthysflesus), analysis of regulatory regions and development of a dual luciferase reporter gene system. Mar. Environ. Res. 50: 1-6.

Yagil, Y. 2013. Camel milk and its unique anti-diarrheal properties. Israel Med. Assoc. J. 15: 35-36.

Yamamoto, A., T. Taniguchi, K. Rikyuu, T. Tsuji, T. Fujita, M. Murakami and S. Muranishi. 1994. Effects of various protease inhibitors on the intestinal absorption and degradation of insulin in rats. Pharm. Res. 11: 1496-1500.

Yasin, S. A. and A. Wahid. 1957. Pakistan camels. A preliminary survey. Agric. Pak. 8: 289-297. 
Yoo, T. J., O. A. Roholt and D. Pressman. 1967. Specific binding activity of isolated light chains of antibodies. Sci. 157: 707-709.

Zhang, S., P. Lei, X. Liu, X. Li, K. Walker, L. Kotha, C. Rowlands and S. Safe. 2009. The aryl hydrocarbon receptor as a target for estrogen receptor-negative breast cancer chemotherapy. Endod. Release Cancer. 16: 835-844.

Ziv, E. and M. Bendayan. 2000. Intestinal absorption of peptides through the enterocytes. Micro. Res. Tech. 49: 346-352. 